\title{
Time Limits for Raising a Set-Off Defence in a Civil Trial
}

\section{Introduction}

The subject of this article is the analysis of the provisions of the Code of Civil Procedure ${ }^{1}$ governing the principles of raising a set-off defence in a civil trial. The reason for addressing this issue is the amendment to the rules of procedure, made by the Act of 4 July 2019. ${ }^{2}$ Within this framework, the legislator introduced into the Code of Civil Procedure Article $203^{1}$, which comprehensively lays down the rules for raising a setoff defence. First of all, it specifies what types of claims may be the basis for a set-off claim, regulates the form in which it can be submitted, and which will be the subject of further considerations - indicates the time limits for raising it. It should be noted that prior to the amendment of 4 July 2019 , the provisions of civil procedure did not contain special provisions regarding the dates on which the allegation of set-off claim could be submitted. Under some separate proceedings, the legislator only provided for restrictions on the admissibility of a set-off claim related to the type of claim that could form its basis (see Art. $505^{4} \S 2$ of the K.p.c., [CCP] Art. 493 $\S 3$ of the K.p.c. [CCP]). ${ }^{3}$ In particular, the lack of time limits regarding

\footnotetext{
* Dr., University of Bialystok; e-mail: k.skrodzki@uwb.edu.pl, https://orcid.org/ 0000-0003-2131-4159.

1 Act of 17 November 1964 Code of Civil Procedure, consolidated text: Journal of Laws of 2020, item 1575, as amended.

2 Act of 4 July 2019 amending the act - Code of Civil Procedure and some other acts, Journal of Laws of 2019, item 1469.

3 It is worth noting that under the amendment of 4 July 2019, the legislator waived additional restrictions on the admissibility of raising a set-off defence in the proceedings
} 
the establishment of the set-off claim often led to situations in which it was used by the defendant not as a form of substantive defence but as a way to prolong the proceedings. By submitting the allegation of set-off at a late stage of the trial, the defendant required the court ${ }^{4}$ to assess it, which usually involved the need for additional evidence and, as a consequence, led to an extension of the time taken to settle the case. ${ }^{5}$ To exclude the possibility of invoking a set-off claim only to prolong the proceedings, the legislator introduced Art. $203^{1} \S 2$ of the K.p.c. [CCP], which stipulates time limits for raising it. Failure to comply with these restrictions will result in the omission of the set-off claim without having to examine its merits.

This article, introducing the legal regulation related to the introduced time limits, aims to draw attention to interpretation doubts regarding the issue of linking the time limit for submitting a set-off with the understanding (definition) of the set-off and the maturity of the claim being the basis for raising it.

\section{Definition of the offset defence and the time limit for raising it}

When discussing the time limitations related to the possibility of raising a set-off defence, one should pay attention to the distinction between the legal act of set-off, regulated by the provisions of the Civil Code, ${ }^{6}$ and the set-off defence, as a procedural act, subject to the provisions of the Code of Civil Procedure. ${ }^{7}$

by writ of payment (Art. $493 \S 3$ of the K.p.c. [CCP] in the wording before the said amendment), see: M. Kostwiński, Set-Off Defence in the Order for Payment Proceedings, Transformacje Prawa Prywatnego 2020, no. 1, p. 31 et seq.

4 Judgment of the Supreme Court of 12 January 2012, II CSK 274/11, LEX no. 1110971.

5 See: justification of the government bill amending the act - Code of Civil Procedure and some other acts, print No. 3137 of the Sejm of the 8th term, p. 173, http:/ / orka.sejm.gov.pl/ Druki8ka.nsf/0/166CCC44490F3965C1258384003CD40A/\%24File/3137-uzas.pdf [access: 20.04.2020].

6 Act of 23 April 1964 Civil Code, consolidated text: Journal of Laws of 2019, item 1145 , as amended.

7 For a broad discussion on the notion and essence of a set-off notice and set-off defence, see M. Pyziak-Szafnicka, Potracenie w prawie cywilnym, Kraków 2002, p. 195 et seq.; see also L. Stępniak, Potracenie w procesie cywilnym, Studia Prawnicze 1973, issue 35, p. 154; 
In accordance with Art. 499 K.c. [Civil Code], deduction occurs through a unilateral legal act of one of the mutual creditors. The effect of this action is the expiry of both parties claims up to the amount of the lower claim (Art. $498 \S 2$ of the K.c. [Civil Code]), as soon as set-off is possible (Art. 499, sentence 2 of the K.c. [Civil Code] in connection with Art. 498 $\S 1$ of the K.c. [Civil Code]). Deduction is a law-shaping act. Its effectiveness requires existence at the time of making certain prerequisites for setoff (Art. 498 § 1 of the K.c. [Civil Code]). Only exceptionally, in certain situations, a specific condition does not need to exist at the moment, but it is sufficient that it existed before (Art. 502, 504, $513 \S 2$ of the K.c. [Civil Code]). It is also clear from the case-law that the requirement of the maturity of the claim, as referred in Art. 498 § 1 K.c. [Civil Code], is fulfilled when only the set-off claim is due. ${ }^{8}$ The deduction statement, as requiring submission to the other party, is made when it is reached so that it can be read (Art. 61, sentence 1 of the K.c. [Civil Code]).

The above remarks refer to the statutory deduction made as part of a unilateral declaration of will. However, within the limits of Art. $353^{1}$ K.c. [Civil Code], it is also permissible to construct offsetting contracts, including multilateral ones, up to which the abovementioned provisions of the Civil Code regulating statutory deductions will not apply. ${ }^{9}$ In the caselaw, it is particularly noted that the claims deducted under the offsetting contract do not have to be homogeneous or even due. ${ }^{10}$ In business practice, contractual deduction is a commonly used solution. ${ }^{11}$

A. Torbus, Procesowy zarzucenia potracenia, in: Rozprawy z prawa prywatnego. Jubilee Book dedicated to Professor Wojciech Popiołek, ed. M. Pazdan, M. Jagielska, E. Rott-Pietrzyk, M. Szpunar, Warsaw 2017, p. 1264 et seq. For the most recent studies, see S. Cieślak, Funkcje zarzutu potracenia w procesie cywilnym oraz w postępowaniu upadłościowym, Transformacje Prawa Prywatnego 2020, no 1, 7-25.

8 Supreme Court judgment of 5 March 2019, II CSK 41/18, OSNC-ZD 2019, no. 4, item 64 .

99 Judgments of the Supreme Court of 10 November 2000, IV CKN 163/00; of 26 January 2005, V CK 404/04, LEX no. 277109; of 20 December 2005, V CSK 68/05, LEX no. 171286.

10 Judgment of the Supreme Court of 3 June 1965, I CR 471/64, OSNC 1966, no. 4 item 1966, item 57 and of 17 December, 1998, II CKN 849/98, OSNC 1999, no. 7-8, item 128; judgment of the Court of Appeals in Krakow of 17 January 2001, I ACa 1022/00, Transformacje Prawa Prywatnego 2003, no. 1, item 121.

11 Attention should be paid to very popular contractual provisions placed under regulations regarding contractual penalties, indicating the authorization of the holder 
The possibility of submitting a deduction statement is not dependent on whether judicial proceedings are pending with respect to the offset covered by the deduction or not. A deduction statement can be made both outside and within the lawsuit. In fact, we can distinguish three cases of time correlation between set-off claims and the civil process related to it. Firstly, offsetting of claims may take place before the initiation of a court dispute (pre-trial offset). Secondly, it may accompany legal proceedings regarding its payment, in such a way that the legal act of the deduction will take place during its duration, but outside of it. The third case is when the defendant as part of the process submits a substantive declaration of will to set off the claim and at the same time relies on it in the form of a demurrer. There is a lack of uniformity of views in the doctrine when defining the accusation of deduction in time correlation with the court process. In particular, the view is presented indicating the need to recognize the charge of offsetting in a narrow (sensu stricto) manner, covering only the third of the cases described above. The accusation of deduction thus understood consists in simultaneous (in the course of the process) submission of a substantive law declaration of will on deduction and submission of a demurrer, claiming that the claim be dismissed in whole or in part due to the done deduction. According to this view, merely invoking as a part of the process the fact that the claimant's claims are being redeemed as a result of a set-off previously made (outside the process) is not a charge of set-off, but a claim of non-existence of the claim requested..$^{12}$ On the other hand, according to the broad understanding of the set-off claim (sensu largo) it does not matter whether the claim to dismiss the complaint and the claim that the claimant's claim does not exist is based on the legal action of the set-off made earlier, in particular before delivering a copy of

\footnotetext{
under a contractual penalty to set-off it with the debtor's liability. In jurisprudence, contractual clauses authorizing the deduction are qualified as offsetting contracts, to which, as a rule, the provisions of the Civil Code regarding unilateral deduction do not apply (see the judgment of the Court of Appeals in Warsaw of 25 April 2014. I ACa 971/13, LEX no. 1488729; judgment of the Court of Appeals in Gdańsk of 29 June 2018, V ACa 261/18, LEX no. 2621569).

12 Compare: M. Pyziak-Szafnicka, Potracenie w procesie cywilnym..., p. 237, A. Torbus, Roszczenie nadające się do potracenia jako warunek dopuszczalności powództwa wzajemnego, in: Wokót problematyki cywilnoprocesowej. Studium teoretycznoprawne. Księga pamiatkowa dla uczczenia pracy naukowej Profesora Kazimierza Korzana, ed. A. Nowak, Katowice 2001, pp. 269-270.
} 
the claim to the defendant or during the trial, together with raising the setoff defence. ${ }^{13}$ In each of these cases, we will be dealing with a set-off defence. The doctrine also presents the position according to which the set-off defence of informative and formative character is distinguished. The first one applies to the situation when the deduction statement was made outside the process, and under it the defendant merely invokes, in the form of an action, information about the fact that the claimant's claims were being waived. The forming charge covers the case in which the declaration of will to set-off is included in the course of an action. ${ }^{14}$

Similar discrepancies in the meaning of the set-off claim occur in court case-law. In justification of the resolution of 19 October 2007 the seven judges of the Supreme Court explained that the set-off claim amounts to submitting a statement on the set-off of mutual claims during court proceedings. In other words, a set-off claim is nothing other than making a set-off statement only in the course of a court dispute. It is not, however, an objection to a set-off, an appeal in the pending proceedings for a set-off made outside the court proceedings. In such a situation, one should speak not of the set-off defence, but of the procedural charge of the non-existence of the claim resulting from the fact that it is being written off in connection with the defendant's statement on offsetting submitted outside the process. ${ }^{15}$ Other Supreme Court rulings, however, indicate that the set-off defence is a reference in court proceedings to the fact of mutual cancellation of claims as a result of offsetting, regardless of when it took place (during or outside the court proceedings). ${ }^{16}$

13 J. Kozak, Rola potracenia w procesie cywilnym, Nowe Prawo 1983, no. 12-13, p. 47; E. Stawicka, Czy i w jakim zakresie zarzut potracenia podniesiony w procesie przerywa bieg przedawnienia roszczenia zgłaszanego do tego potracenia?, Palestra 2008, no. 9-10, p. 256; P. Telenga, in: Kodeks postępowania cywilnego. Komentarz do wybranych przepisów nowelizacji, 2019, Commentary on Art. 2031, thesis 2; G. Wolak, O formie złożenia oświadczenia woli o potraceniu oraz zarzutu potracenia, Monitor Prawniczy 2010, no. 23, pp. 1294-1295.

14 A. Torbus, in: Kodeks postępowania cywilnego. Koszty sadowe w sprawach cywilnych. Dochodzenie roszczeń w postępowaniu grupowym. Przepisy przejściowe. Komentarz do zmian, ed. T. Zembrzuski, 2019 [LEX database], Commentary on Art. 203', theses 3 and 4.

15 Resolution of seven judges of the Supreme Court of 19 October 2007, III CZP 58/07, OSNC 2008, no. 5, item 44.

16 Judgments of the Supreme Court of 12 March 1998, I CKN 522/97, OSNC 1998, no. 11, item 176; of 12 March 1998, I CKN 522/97, OSNC 1998, no. 11, item 176; of 7 May 2004, I CK 666/03, OSNC 2005, no. 5, item 86. 
The provision of Art. $203^{1}$ of the K.p.c. [CCP] added pursuant to the amendment of 4 July 2019 does not define a set-off defence, and therefore does not explicitly remove the discrepancies referred to above in its understanding. ${ }^{17}$ It seems that this ground of complaint should be understood broadly. ${ }^{18}$ The set-off defence will therefore cover both stricte procedural act, referring to a set-off of legal action taken outside of court proceedings, but may also combine a procedural act and a declaration of will to set off. The teleological interpretation of Art. $203^{1}$ of the K.p.c. [CCP] favors such an understanding of set-off defence. It was explained at the outset that the reason for the introduction of the analyzed provision was the limitation of the possibility of relying on a set-off defence at late stages of the proceedings, only to prolong the trial. Recognizing this intention of the legislator, it must be assumed that his intention was for the introduced time restrictions to have the widest possible application. If, however, we consider that the set-off defence covers only the situation of a simultaneous combination of the act of offset and the procedural act, then Art. 203 $\S 2$ of the K.p.c. [CCP] will have significantly limited use. Outside the scope of its regulation, there would be cases in which a statement on set-off was admittedly being made in parallel to the trial, but outside it. It would also be relatively easy to circumvent the time limits set by this provision by making out-of-process declarations of will regarding set-off and relying on it as alleging that the claimant's claim does not exist. ${ }^{19}$

For similar, purposeful reasons, such an interpretation of Art. $203^{1}$ of the K.p.c. [CCP], according to which the set-off defence would consist not

17 See A. Olaś, Dopuszczalność zarzutu potracenia w postępowaniu cywilnym - uwagi na tle projektu Ministra Sprawiedliwości ustawy o zmianie ustawy - Kodeks postępowania cywilnego oraz niektórych innych ustaw z 27.11.2017 r., Polski Proces Cywilny 2019, no. 2, p. 150.

18 Similarly, M. Kostwiński, 'Set-Off Defence in the Order for Payment Proceedings', Transformacje Prawa Prywatnego 2020, no. 1, p. 42. In contrast: Ł. Blaszczak, Zarzut potracenia w procesie cywilnym (art. 2031 K.p.c.), Warszawa 2019, p. 97 et seq. According to this author, it seems appropriate to assume that the set-off defence referred to in Article 203, Art. $505^{4} \S 2$ and Art. $840 \S 1$ item 2 of the Code of Civil Procedure, is connected with the procedural set-off defence, which is made during the pending proceedings. If the legislator in the Code of Civil Procedure uses the term 'set-off defence', it is only to indicate a procedural situation in which, during already initiated proceedings, an defence is made in which the defendant expresses his will to set off and to dismiss the action as a result of such set-off.

19 See T. Szanciło, in: Kodeks postępowania cywilnego. Komentarz. Art. 1-50539, ed. T. Szanciło, 2019 [Legalis database], Commentary on Art. 203리 nb 8. 
only of appealing to the unilateral legal act of offsetting in the process, but also included the case of invoking contractual offsetting, resulting in mutual waiver of claims.

\section{The Deadline for Submitting a Set-off Defence before the Amendment of 4 July 2019}

Before the amendment of 4 July 2019, the Code of Civil Procedure did not contain provisions strictly specifying the deadline for submitting a setoff defence. As it has already been noted, in the light of substantive law it is indifferent when a deduction statement is submitted and it can take place both when legal proceedings are not pending with respect to the given claims and when it has already been initiated. The judicial decision emphasized that if substantive law does not specify the date of exercising the substantive right or the period has not expired, the party may use it at the time it deems appropriate and refer in the process to the resulting effect. ${ }^{20}$ The set-off defence, as a procedural act, consisting in invoking a certain fact and the legal consequences resulting therefrom, is, however, subject to the norms of conduct determining to which facts can be presented (the relevant provisions were: Art. 3, Art. 217 § 1, Art. 381, Art. 3981, Art. $843 \S 3$ of the K.p.c. [CCP]). ${ }^{21}$

With the above in mind, the set-off concerning the deduction made before the initiation of the proceedings or in the course of the first instance could only be raised before the close of the trial at first instance. Admittedly, Art. 381 of the K.p.c. [CCP] did not exclude the possibility of raising the set-off defence made before the initiation of the proceedings or in the course of the first instance also in appeal proceedings, however, the fact of set-off made at that time could be omitted by the court of appeal, due to the fact that it could be appointed in the proceedings before the court of first instance. On the other hand, the deduction made after closing the trial at first instance or during the second instance could be effectively relied on in the form of an objection only before the closing of the appeal

20 Judgment of the Supreme Court of 9 March 2016, II CSK 354/15, LEX no. 2062787.

${ }^{21}$ Judgment of the Supreme Court of 23 January 2004, III CK 251/02, LEX no. 197447. 
hearing. ${ }^{22}$ Submission of the set-off defence in appeal proceedings was, however, subject to the limitations of evidence provided for at this stage of the court proceedings. This meant limiting the effective reference to this charge to the limits of the facts already demonstrated before the court of first instance or circumstances based on new facts and evidence admissible in proceedings before the court of appeal (Art. 382 of the K.p.c. [CCP]). ${ }^{23}$ On the other hand, since the basis for the cassation appeal could only be a violation of the law, in cassation proceedings it was unacceptable to raise a defence referring even to a deduction made in the course of this procedure. ${ }^{24}$ On the other hand, the set-off defence made after the execution title was raised as part of an anti-enforcement suit (Art. $840 \S 1$ item 2 of K.p.c. $[\mathrm{CCP}]) .{ }^{25}$ In addition, the set-off defence could have been the basis for an anti-enforcement suit, even if the plaintiff could still have it raised in the examination of the case in which the writ of execution was issued. ${ }^{26}$

To sum up, before the amendment of 4 July 2019, the judicial decision was dominated by the position according to which only in the case of an allegation referring to a pre-trial offsetting, the defendant had the procedural burden of invoking this fact within a specified period, otherwise the allegation would be omitted. However, the situation was different in relation to the complaint combining the legal act of offsetting and the procedural act. The defendant, at his will, could use the offset at the beginning of the proceedings, in the first and second instance, or only in the enforcement proceedings. The judicial decisions emphasized that since the deadline for submitting a declaration of will does not follow from the Civil Code, procedural law cannot interfere in the right to shape the defendant who wants to use it, for example, only after the final settlement of the dispute. ${ }^{27}$

22 Judgment of the Supreme Court of 9 October 2003, V CK 319/02, LEX no. 82267.

${ }^{23}$ Judgment of the Court of Appeals in Katowice of 21 May 2013, V ACa 638/12, LEX no. 1322483; judgment of Appeal Court in Poznań of 28 May 2014, I ACa 308/14, LEX no. 1489128; judgment of the Court of Appeals in Białystok of 15 January 2016, I ACa 931/15, LEX no. 1962883.

${ }^{24}$ See: the Supreme Court judgment of 10 June 1997, II CKN 180/97, OSNC 1997, no. 12 item 202, corrected: OSNC 1998, book 1, p. 105.

25 Judgment of 12 March 1998, Supreme Court, I CKN 522/97, OSNC 1998, no. 11, item 176.

26 Supreme Court decisions of 28 March 1972, I CR 396/71, OSPiKA 1973, no. 7-8, item 151; of 14 October 1993, III CZP 141/93, OSNC 1994, no. 5, item 102; of 6 April 2017, IV CNP 40/16, LEX no. 2310116.

27 Judgment of the Supreme Court of 9 March 2016, II CSK 354/15, LEX no. 2062787. 


\section{Time Limits in Raising the Set-off Defence in the Current Legal Status}

In accordance with Art. $203^{1} \S 2$ of the K.p.c. [CCP] the defendant may raise the set-off defence no later than when entering into the dispute as to the merits of the case. Therefore, this defence should be made at the latest at the time of entering into the dispute as to the merits of the case, i.e. together with the first act of the defendant, in which he may raise substantive allegations regarding the statement of claim. This may occur in response to the claim, and if it was not required, when the oral position was taken for the first time as to the merits of the dispute. A defence may also be made in opposition to a default judgment, in an order for payment in an order proceedings or in an objection to a payment order in a writ proceedings. It can be seen from the above that this defence can be effectively raised at the initial stage of the proceedings, together with the defendant's first act in which he undertakes substantive defence against the claimant's claim.

There is no doubt that the time limits referred to above relate to the defence based on the deduction made at the pre-trial stage. If the set-off took place before the initiation of the trial (at the latest before delivery of the copy of the claim to the defendant), raising the defence of set-off, the defendant should comply with the above time limits under pain of omitting the defence. Offsetting, as a legal act, may, however, also take place when the judicial proceedings are already at a later stage, which means that the procedural set-off of defence will update after getting into the dispute as to the merit of the case. Pursuant to the aforementioned judicial decision, developed on the basis of the provisions prior to the amendment of 4 July 2019, showed that if substantive law does not specify the date of exercising the substantive right or the period has not expired, the party may use it at the time she/he deems appropriate and consequently invoke the resulting effect in the ongoing process. The fact that the claimant's and the defendant's mutual claims are cancelled will constitute a new fact, which the possibility of filing arises only at the time when the offsetting legal act is performed. Therefore, the question arises whether the provision of Art. $203^{1} \S 2$ of the K.p.c. [CCP] may be interpreted as excluding the possibility of referring to a set-off in the trial when it was made after entering into a dispute as to the merit of the case. The doctrine recognizes that the legislator may limit substantive rights of civil law entities in procedural law, however, this requires explicit regulation. 
Without a clear indication, procedural provisions should not limit the material rights of the parties, and in case of doubt they should be resolved in favor of substantive law regulations. ${ }^{28}$ With the wording of Art. $203^{1}$ $\S 2$ of the K.p.c. [CCP] in mind, it should be acknowledged that the limit of entering into a dispute indicated in it excludes the possibility of raising defences based on a legal act of an offsetting made after exceeding it. This position corresponds to the view presented above, which indicates a broad understanding of the set-off defence. Allowing a different interpretation would mean that for the offsetting that followed the dispute over the merit of the case, the general rules of procedure for reporting statements and evidence will apply (Art. $205^{3} \S 2,215^{12}$ K.p.c. [CCP]). Therefore, the setoff defence could also be admissible at the stage of the appeal proceedings if the legal act of the offsetting was made at that time (Art. 381 of the K.p.c. $[\mathrm{CCP}])$. This kind of interpretation would mean exempt from the pain of the provision of Art. $203^{1}$ of the K.p.c. [CCP] of a significant part of the set-off defences, which in consequence could mean nullifying the objectives associated with its introduction.

The time limit for entering into the dispute as to the merits of the case does not apply, however, to filing a defence, if the claim submitted for offsetting became payable only during court proceedings. In this case, the defence should be raised within 2 weeks from the due date of the defendant's claims. This means that a set-off defence can also be effectively made in proceedings before the second court instance, if its earlier raising was not possible due to the fact that the defendant's claim was not due yet.

Due to the legislator's linking the deadline for raising the set-off defence with the defendant's maturity, interpretation problems may relate to situations in which the submission of the claim due depends - in accordance with substantive law - on the defendant's activity. Such cases will be related to the regulation of Art. 455 K.c.[Civil Code], regarding indefinite obligations. Pursuant to this provision, if the date of performance is not specified or results from the nature of the obligation, the benefit should be met immediately after the debtor's request to perform. The effect of the creditor's call for the benefit to be paid is that it becomes payable.

28 J. Górowski, in: Kodeks postępowania cywilnego, vol. 2: Komentarz: Art. 2051-42412, ed. A. Marciniak, 2019 [Legalis database], Commentary on Art. 217, nb 11. 
The due date of the benefit is the end of the last day, which was defined as the date of fulfilment. ${ }^{29}$ Therefore, the judicial decision assumes that maturity is the first time within which a creditor could bring an action for awarding a court and the court could take such action the same day (Art. $316 \S 1$ of K.p.c. [CCP]). ${ }^{30}$

It should be noted - which is important in the light of Art. 203 $\S 2$ of the K.p.c. [CCP] that the provisions of the Civil Code do not contain regulations forcing the creditor to call the debtor in order to make the debt payable. Only the provisions on limitation of claims show that the limitation period begins from the date on which the claim becomes due. However, if the maturity of the claim depends on the taking of a specific action by the beneficiary, the limitation period will begin from the date on which the claim would become payable if the beneficiary took action as soon as possible (Article $120 \S 1$ of the K.c. [Civil Code]). ${ }^{31}$ Comparing provisions of Art. $203^{1} \S 2$ of the K.p.c. [CCP], which binds the deadline for raising the set-off defence with the due date of the defendant's claims, with the provisions of the Civil Code regarding indefinite obligations, which do not imply the creditor's obligation to take actions leading to due date, may guide on a request that the procedural provisions are ineffective. Since the creditor (defendant), under substantive law, may freely decide about the time when his claim is due, he/she also indirectly has the opportunity to shape the moment for raising the set-off

29 See justification of the Supreme Court resolution of 26 November 2009, III CZP 102/09, OSNC 2010, no. 5, item 75 and the justification of the judgment of the Supreme Court of 28 October 2015, II CSK 822/14, LEX no. 1930449.

30 It should be clarified that the judicial decision also presented the view that differentiates the requirement of the claim, understood as the earliest moment in which the creditor may request the benefit of the debtor and the date of performance, understood as the latest moment in which the debtor should meet the benefit in accordance with its content (see Supreme Court rulings of 6 March 1991, III CZP 2/91, OSNC 1991, no. 7, item 93; of 22 March 2001, V CKN 769/00, OSNC 2001, no. 11, item 166). Currently, the judicial decision is dominated by the concept combining the enforceability of claims arising from indefinite obligations with the arrival of the last day allowing the debtor to meet the benefit (comp. Supreme Court judgment of 29 November 1999, III CKN 474/98, Wokanda 2000, no. 2, p. 1; of 17 May 2000, I CKN 302/00, LEX no. 52411; of 21 February 2002, IV CKN 793/00, OSNC 2003, no. 2, item 22; of 24 April 2003, I CKN 316/01, OSNC 2004, no. 7-8, item 117; of 8 July 2010, II CSK 126/10, LEX no. 602678; Resolution of the Supreme Court of 22 November 2013, III CZP 72/13, OSNC - Coll. 2014, no. B, item 40).

31 Judgment of the Supreme Court of 30 June 2011, III CSK 282/10, LEX no. 898707. 
defence in the process. It can also be mentioned that in practice the set-off defence very often concerns the defendant's claims under contractual penalties or obligations for damages, including those arising from the delay of the debtor, whose maturity depends on the request for payment. ${ }^{32}$ The analyzed issue will therefore have significant practical significance.

With the above in mind, such an interpretation of the provision of Art. $203^{1} \S 2$ of the K.p.c. [CCP], according to which the time limit for raising a set-off defence will come into effect not the actual maturity of the defendant's claims, but the moment when it would become due if he took the decisive act at the earliest possible date. This interpretation of the provision would be supported by a teleological interpretation. It has already been pointed out that its sense was to specify strict time limits for raising a set-off defence in order to eliminate the practice of reporting it at any stage of the process. Achieving such an intention will certainly not be possible in the case of indefinite claims, since their due date, and thus the validity of the set-off defence, depends on the defendant's behaviour.

For indefinite liabilities, however, the issue is still important. From the provision of Art. 455 K.c. [Civil Code], results that the indefinite obligation becomes due immediately after the debtor is called to perform the service. The creditor does not need to indicate the date of performance in the request, because it results directly from Art. 455 K.c. [Civil Code], (immediately after calling the debtor for enforcement). However, he may request the debtor to meet the benefit later than immediately. ${ }^{33}$ In view of the above, the defendant, by setting a specific period (sufficiently long), the expiry of which results in the maturity of the claim, may cause that the set-off defence will not become valid until the end of the proceedings before the court of first instance or even during the appeal proceedings.

With the above in mind, the question arises as to whether the court could consider a late set-off defence, assuming that the deadline set by the defendant for determining the service's due date and timeliness reported in the course of the defence is unreasonably long. You have to stand on the position that the court does not have such competence.

32 Resolution of the Supreme Court of 5 November 2014, III CZP 76/14, OSNC 2015, no. 7-8, item 86; Supreme Court judgment of 19 September 2000, IV CKN 92/00, OSNC 2001, no. 3, item 36.

33 K. Zagrobelny, in: Kodeks Cywilny. Komentarz, eds. E. Gniewek, P. Machnikowski, Warsaw 2017, p. 979; J.P. Naworski, Glosa to the Supreme Court judgment of 23 October 2001, I CKN 323/99, Company Law 2005, no. 2, p. 43. 
Admittedly, the opposite view would be supported by the purpose of introducing Art. $203^{1} \S 2$ of the Civil Procedure Code, as well as the content of the provision of Art. 455 K.c. [Civil Code], which directly indicates that, as a rule, the benefit should be fulfilled immediately from the date of the summons, but its acceptance would constitute an unacceptable interference in the substantive law action of the defendant, without explicit authorization in the procedural provisions.

Considering the above doubts in interpretation, concerning the time limitations resulting from Art. $203^{1} \S 2$ of the K.p.c. [CCP] related to the possibility of raising a set-off defence, it should also be pointed out that the provision of Art. $840 \S 1$ point 2 of the K.p.c. [CCP] was also amended based on the amendment of 4 July 2019, namely: in its new wording, this provision directly gives grounds for bringing an anti-enforcement suit based on a set-off defence. According to the position presented in the available literature, the notion of 'a set-off defence', as intended by the legislator, primarily includes - under Art. $840 \S 1$ point 2 of the K.p.c. $[\mathrm{CCP}]$ - those cases which do not fall within the scope of the terms already used in the Act, i.e. 'an event which occurred after the hearing was closed' and 'charge of fulfilment of a provision whose notification in the hearing was inadmissible by virtue of the Act' ${ }^{34}$ This means that a set-off defence which, due to time limitations under Art. $203^{1} \S 2$ of the K.p.c. [CCP], would be inadmissible in the process of fulfilling an obligation, could constitute a basis for a specific challenge to the ruling made in it in the anti-enforcement suit. Considering such an interpretation of the provision of Art. $840 \S 1$ point 2 of the K.p.c. [CCP] and the term 'set-off defence' used in it as appropriate would decrease the number of cases in which the defendant, particularly by filing a late set-off claim, would - after the trial - be deprived of both the possibility of effectively pursuing their own claim in the case for payment and the possibility of effectively stopping the enforcement against them. On the other hand, extending the grounds of an anti-enforcement suit for a set-off defence, which was not possible in a process of fulfilling an obligation, will result in nothing more than increased number of such trials.

34 A. Sadza, Zarzut spetnienia świadczenia jako podstawa powództwa opozycyjnego (Art. 840 $\S 1$ point 2 in fine KPC) - konsekwencje dla wykładni przepisów o potrąceniu w procesie cywilnym, Przegląd Prawa Egzekucyjnego 2019, no. 8, p. 14. 


\section{Conclusion}

The regulation of the provision of Art. $203^{1} \S 2$ of the K.p.c. [CCP] generally, may be evaluated positively. The legal status prior to the amendment of 4 July 2019, according to which the defendant could raise the set-off defence at almost every stage of the trial was not conducive to the efficiency of the proceedings and created scope for abuse in using this defence. However, the discussed regulation raises interpretation doubts.

The first, as outlined above, concerns the very understanding of the set-off defence. In this case, it seems sufficient to reach only for a teleological interpretation and to recognize that the provision of Art. $203^{1}$ of the K.p.c. [CCP], refers to the broad understanding of the set-off defence.

The second issue is clarifying whether the provision of Art. $203^{1} \S 2$ of the K.p.c. [CCP] pointing to entering into a dispute as to the merits of the case, as the final moment to raise a set-off defence, excludes the possibility of relying on that defence at all, in situation where the legal act of offsetting was made after that time. It must be acknowledged that this was the intention of the legislator, but one can postulate to clarify the provision in this respect.

The third doubt concerns indefinite liabilities, for which the provision of Art. $203^{1} \S 2$ of the K.p.c. [CCP] does not objectively determine the time of the initial running of the deadline for submitting a set-off defence. With the intention of the legislator in mind, accompanying the introduction of Art. $203^{1} \S 2$ of the K.p.c. [CCP], such an interpretation of this provision has been presented above where the time limit for raising a defence of setoff is related not to the actual maturity date of the defendant's claim, but to the moment at which it could occur at the earliest. Despite such a suggestion of an interpretation, the postulate of the legislator's interference in the discussed scope seems to be justified and clear determination in the content of the provision that in the case of making the debt repayment dependent on a specific act of the defendant, the time limit for raising the set-off defence begins from the day on which the debt would become due if he took action as soon as possible.

The amendments discussed herein, introducing time limitations in raising a set-off defence, will undoubtedly shorten the time needed for dealing with court cases as when a set-off defence is raised in violation of the applicable time limits, the court will be relieved from the obligation to examine the validity of such a claim. However, as already stated, by 
introducing Art. $203^{1}$ of the K.p.c. [CCP] the legislator extended the basis for an anti-enforcement suit with the notion of a set-off defence (Art. 840 $\S 1$ point 2 of the K.p.c. [CCP]). The set-off defence, from the examination of which the court could be relieved in the process of fulfilling an obligation, might therefore become the basis of a new (anti-enforcement) trial during which its effectiveness would be assessed.

\section{Bibliography}

Błaszczak Ł., Zarzut potracenia w procesie cywilnym (art. 2031 K.p.c.), Warszawa 2019.

Cieślak S., Funkcje zarzutu potracenia w procesie cywilnym oraz w postępowaniu upadtościowym, Transformacje Prawa Prywatnego 2020, no. 1.

Górowski J., w: Kodeks postepowania cywilnego, vol. 2: Komentarz: Art. 2051-42412, ed. A. Marciniak, Warszawa 2019.

Kostwiński M., Zarzut potracenia w postępowaniu nakazowym, Transformacje Prawa Prywatnego 2020, no. 1.

Kozak J., Rola potracenia w procesie cywilnym, Nowe Prawo 1983, no. 12-13.

Naworski J.P., Glosa do wyroku SN z 23 października 2001 r., I CKN 323/99, Prawo Spółek 2005, no. 2.

Olaś A., Dopuszczalność zarzutu potracenia w postępowaniu cywilnym - uwagi na tle projektu Ministra Sprawiedliwości ustawy o zmianie ustawy - Kodeks postępowania cywilnego oraz niektórych innych ustaw z 27.11.2017 r., Polski Proces Cywilny 2019, no. 2.

Stawicka E., Czy $i$ w jakim zakresie zarzut potracenia podniesiony w procesie przerywa bieg przedawnienia roszczenia zgłaszanego do tego potracenia?, Palestra 2008, no. 9-10.

Pyziak-Szafnicka M., Potracenie w prawie cywilnym, Kraków 2002.

Sadza A., Zarzut spetnienia świadczenia jako podstawa powództwa opozycyjnego (art. 840 § 1 pkt 2 in fine K.p.c.) - konsekwencje dla wykładni przepisów o potraceniu w procesie cywilnym, Przegląd Prawa Egzekucyjnego 2019, no. 8.

Stępniak L., Potracenie w procesie cywilnym, Studia Prawnicze 1973, issue 35.

Szanciło T., in: T. Szanciło, Kodeks postępowania cywilnego. Komentarz. Art. 1-50539, Warszawa 2019.

Telenga P., in: Kodeks postępowania cywilnego. Komentarz do wybranych przepisów nowelizacji 2019, ed. A. Jakubecki, Warszawa 2019.

Torbus A., Roszczenie nadające się do potrącenia jako warunek dopuszczalności powództwa wzajemnego, in: Wokót problematyki cywilnoprocesowej. Studium 
teoretycznoprawne. Ksiegga pamiatkowa dla uczczenia pracy naukowej Profesora Kazimierza Korzana, ed. A. Nowak, Katowice 2001.

Torbus A., Procesowy zarzut potracenia, in: Rozprawy z prawa prywatnego. Ksiega jubileuszowa dedykowana Profesorowi Wojciechowi Popiołkowi, eds. M. Pazdan, M. Jagielska, E. Rott-Pietrzyk, M. Szpunar, Warszawa 2017.

Torbus A., in: Kodeks postępowania cywilnego. Koszty sadowe w sprawach cywilnych. Dochodzenie roszczeń w postępowaniu grupowym. Przepisy przejściowe. Komentarz do zmian, ed. T. Zembrzuski, Warszawa 2019.

Wolak G., O formie złożenia oświadczenia woli o potrąceniu oraz zarzutu potrącenia, Monitor Prawniczy 2010, no. 23.

Zagrobelny K., w: Kodeks cywilny. Komentarz, eds. E. Gniewek, P. Machnikowski, Warszawa 2017.

\section{Summary}

The article discusses the regulation of the provision of Art. $203^{1} \S 2$ of the K.p.c. [CCP], establishing time limits in raising a set-off defence in a civil trial. The analysis focuses in particular on three issues. Understanding (definition) of the set-off defence, which is reflected in the scope of application of time limits resulting from Art. $203^{1} \& 2$ of the K.p.c. [CCP]. This provision excludes the possibility of invoking a set-off where it occurred after getting into a dispute as to the merits of the case. In addition, the article points to interpretation problems arising from the connection between the time limit for raising a defence of set-off and the defendant's due date. The considerations made finally allow for the submission of proposals for the interpretation of Art. $203^{1} \S 2$ of the K.p.c. [CCP] and making de lege ferenda postulates.

Key words: deduction, set-off defence, defence of the defendant in the trial, course of action, amendment to the Code of Civil Procedure

\section{OGRANICZENIA CZASOWE W PODNOSZENIU ZARZUTU POTRĄCENIA W PROCESIE CYWILNYM}

\section{Streszczenie}

Artykuł omawia regulację przepisu art. $203^{1} \S 2$ K.p.c., ustanawiającą ograniczenia czasowe $w$ podnoszeniu zarzutu potrącenia w procesie cywilnym. Analiza koncentruje się w szczególności wokół trzech kwestii. Rozumienia (definicji) zarzutu potrącenia, co przekłada się na zakres zastosowania ograniczeń czasowych 
wynikających z art. $203^{1} \S 2$ K.p.c. Wyłączenia przez ten przepis możliwości powoływania się na potrącenie w sytuacji, gdy miało ono miejsce po wdaniu się w spór co do istoty sprawy. Ponadto artykuł wskazuje na problemy interpretacyjne wynikające z powiązania terminu na podniesienie zarzutu potrącenia $\mathrm{z}$ wymagalnością wierzytelności pozwanego. Przeprowadzone rozważania pozwalają końcowo na przedstawienie propozycji interpretacji art. $203^{1} \S 2$ K.p.c. oraz wysunięcie postulatów de lege ferenda.

Słowa klucze: potrącenie, zarzut potrącenia, obrona pozwanego w procesie

\section{ВРЕМЕННЫЕ ОГРАНИЧЕНИЯ ПРИ ПРЕДЪЯВЛЕНИИ ИСКА О ВЫЧЕТЕ В ГРАЖДАНСКОМ ПРОЦЕССЕ}

В данной статье рассматривается регулирование статьи $203^{1} \S 2$ Гражданского процессуального кодекса, устанавливающей временные ограничения при предъявлении иска о вычете в гражданском процессе. Особое внимание в анализе уделяется трем вопросам. Понимание (определение) возражения против иска о вычете, что влияет на область применения временных ограничений, предусмотренных ст. $203^{1} \S 2$ Гражданского процессуального кодекса. Исключение этим положением возможности ссылаться на вычет в ситуации, когда он имел место после рассмотрения спора по существу. Кроме того, в статье указывается на проблемы толкования привязки срока предъявления иска о вычете со сроком погашения иска ответчика. Наконец, автор предлагает толкование статьи $203^{1} \S 2$ Гражданского процессуального кодекса и постулирует de lege ferenda.

Ключевые слова: вычет, предъявление иска о вычете, защита ответчика в судебном процессе 
